\title{
RESPONSE OF SOME RICE (Oryza sativa L.) CULTIVARS TO GERMINATION UNDER SALINITY STRESS
}

\author{
KANDIL A.A. ${ }^{1}$, SHARIEF A.E. ${ }^{1}$ AND NASSAR E.S.E²
}

1Department of Agronomy, Faculty of Agriculture, Mansoura University, Egypt.

${ }^{2}$ Central Administration for Seed certification (CASC), Ministry of Agriculture, Egypt.

${ }^{*}$ Corresponding Author: Email- sharief2005@yahoo.com

Received: July 01, 2012; Accepted: July 18, 2012

\begin{abstract}
The purpose of this study was found out to investigate the response of some rice (Oryza sativa L.) cultivars to germination parameters under salinity stress. This study was carried out to confirm rice seedling growth performance and to examine a range of genetic variability for salinity tolerance among ten rice cultivars under seven salinity levels. A laboratory experiment was accompanied at Giza Central Seed Testing laboratory (CASC), Egypt. The results showed that rice cultivars significantly varied in means of Final Germination Percentage (FGP), Germination Rate (GR), Germination Index (GI), Vigor Index (VI), Root Length, Shoot Length, Root Fresh Weight, Shoot Fresh Weight, Root Dry Weight, Relative Dry Weight and Seedling Height Reduction. Sakha 102 and Sakha 106 had positive effects in most of studied characters while, Giza 181 cultivar had negative effects in most of germination parameters under study. Salinity levels significantly varied in all germination parameters under study except shoot dry weight character. Increasing salinity concentration from 0 to $14 \% \mathrm{NaCl}$ gradually reduced averages of germination and seedling characters. All studied characters were significantly affected by the interaction between cultivars and salinity stress, vice versa, shoot, root fresh weight and root dry weight didn't affect by interaction. It could be established that for exploiting rice germination percentage and seedling parameters under salinity stress are recognized by using rice Sakha 102, Sakha 106, Sakha 104 and Egyptian Yasmin cultivars with increasing salinity levels up to $14 \% \mathrm{NaCl}$. These cultivars were more tolerant to salinity and suggested to use in breeding program for attractive rice production in Egypt .
\end{abstract}

Key words- Oryza sativa, salinity concentration, germination characters, rice cultivars, seedling parameters

Citation: Kandil A.A., Sharief A.E. and Nassar E.S.E. (2012) Response of Some Rice (Oryza sativa L.) Cultivars to Germination Under Salinity Stress. International Journal of Agriculture Sciences, ISSN: 0975-3710 \& E-ISSN: 0975-9107, Volume 4, Issue 6, pp-272-277.

Copyright: Copyright@2012 Kandil A.A., Sharief A.E. and Nassar E.S.E. This is an open-access article distributed under the terms of the Creative Commons Attribution License, which permits unrestricted use, distribution and reproduction in any medium, provided the original author and source are credited.

\section{Introduction}

Rice is considered as a major cereal crop for more than $50 \%$ of the world population. There is a great shortage in rice production more than $25 \%$ of the recent production may be needed [1]. Moreover, rice ranks second after wheat crop as the national income is concerned. The excessive increase in population in Egypt needs to increase the total yield of this crop in order to overcome this lack in production through its cultivation in the newly reclaimed lands especially under saline conditions of such soil. Rice is one of the most effective and commercial means of reclaiming hundreds of thousands of hectares of saline lands in Egypt. Growth characters including shoot height, fresh weight, dry weight and leaf area of salt-stressed seedlings were inhibited, depending on rice genotypes [2]. Rice varieties showed a great variation in germination due to salinity effects. Many investigators concluded that differences among rice cultivars in germination characters and seedling parameters $[3,15,17,22]$.

Salinity is one of the major obstacles in enhancing rice production in growing areas in Egypt. Salinity decreases final germination percentage, speed of germination and led to reduction in shoot and root length and dry weight in all varieties and the magnitude of reduction increased with increasing salinity stress [11]. Therefore, development of salt tolerance varieties has been considered as one of strategies to increase rice production in saline prone 
areas or irrigation with mixed water at the end of water rivers. Salt stress decreased seed vigor of rice cultivars, LD a superior cultivar under all salt stress which can be suggested for cultivation under salinity condition was obtained. [12,14,17,20,22].

It is very important to study the interaction effects of variability of sodium chloride effects within studied rice varieties $[3,11,17]$. The objectives of this research were aimed to study the performance of cultivars and salinity stress and their interactions on germination parameters of rice plants under laboratory conditions.

\section{Materials and Methods}

A laboratory experiment was conducted at Giza Central Seed Testing laboratory of Central Administration for Seed Testing and Certification (CASC), Ministry of Agriculture, Egypt during the period of December 2011 to January 2012 to study the response of rice (Oryza sativa L.) cultivars to germinate it under salinity stress and to confirm the seedling growth performance to examine a range of genetic variability for salinity tolerance among rice cultivars.

\section{Treatments and Experimental Design}

The experiment was arranged in factorial experiment in Randomized Complete Block Design (RCBD) with four replications. The experiment included 10 different rice cultivars which were gotten from Rice Research Institute at Sakha, ARC, MOA, Egypt. Studied rice cultivars were stored under normal conditions in paper bags include 5 cultivars belong to Japonica type and 5 cultivars belong to Indicia type as showed in Table 1. Seven different salinity concentrations $(\mathrm{NaCl})$ i.e. $0,4 \%, 6 \%, 8 \%, 10 \%, 12 \%$ and $14 \% \mathrm{NaCl}$ were used. Seeds of cultivars were surface sterilized by immersion for 5 minutes in sodium hypochlorite solution, then repeatedly washed with deionized water. Fifty seeds of uniform size in each treatment for each cultivar were allowed to germinate on a filter paper in $9 \mathrm{~cm}$ diameter petredishes. Each filter paper was moistened with a water solution at seven different $\mathrm{NaCl}$ concentrations. Thus, the whole experiment comprised 280 Petri dishes arranged in factorial experiment Randomized Complete Block Design (RCBD). The Petri dishes were placed in a growth chamber for 14 days at $28 \pm \mathrm{C}^{0}$ for germination.

Table 1- Name, type, pedigree and year of release of studied cultivars

\begin{tabular}{|lllll|}
\hline No & Name of Genotypes & Type & Pedigree & $\begin{array}{l}\text { Year of } \\
\text { release }\end{array}$ \\
\hline 1 & Sakha 102 & Japonica & GZ4096-7-1/GZ4120-2-5-2(Giza 177) & 1997 \\
2 & Sakha 104 & Japonica & GZ4096-8-1/GZ4100-9 & 1999 \\
3 & Sakha 105 & Japonica & GZ5581-46-3/GZ4316-7-1-1 & 2010 \\
4 & Sakha 106 & Japonica & Giza177/Hexi30 & 2010 \\
5 & Giza 178 & Japonica & Giza175/Milyang49 & 1995 \\
6 & Giza 181 & Indica & IR24/IR22 & 1988 \\
7 & Giza 182 & Indica & Giza181/ir39422-161-1-3//Giza181 & 1999 \\
8 & Egyptian Yasmin & Indica & IR262-43-8-1/ NAHNG SARN & 1992 \\
9 & Egyptian Hybrid 1 & Indica & IR69625A× Giza178R & 2005 \\
10 & Egyptian Hybrid 2 & Indica & IR69625A×Giza181R & 2007 \\
\hline
\end{tabular}

\section{Studied Characters}

After 14 days ten seedlings were selected from each replicates and then seedlings were evaluated as follows:

- Final Germination Percentage (FGP): FGP was calculated according to the following equation $[7,19]$.

$$
(\mathrm{FGP})=\frac{\text { Number of Germinated Seed }}{\text { Total Number of Seed Tested }} \times 100 \text {. }
$$

- Germination Rate (GR): it was calculated according the following equation [6].

$$
(G R)=\frac{\text { Number of Germinated Seeds }}{\text { Number of Germination Days }}
$$

- Germination Index (GI): according to the following equation described by [16]. It was calculated according the following equation.

$$
(\mathrm{GI})=\frac{\% \text { Germination Each Treatment }}{\text { \%Germination in the Control }}
$$

- Vigor index (VI): it was calculated according to the following equation:

(VI) : (Average Shoot Length + Average Root Length) $\times$ Germination Percentage

- Root length $(\mathrm{cm})$.

- Shoot length (cm).

- Root fresh weight (mg).

- Shoot fresh weight (mg).

- Root dry weight (mg).

- Shoot dry weight (mg).

- Relative dry weight (RDW): It was calculated according to the following equation described by [12].

$$
\text { RDW }(\%)=\frac{\text { Total Dry Weight under Saline Condition }}{\text { Total Dry Weight under Control Condition }} \times 100
$$

- Seedling height reduction (SHR): It was calculated using the following equation described by [12].

$$
\operatorname{SHR}(\%)=\frac{\text { Plant Height at Control }- \text { Plant Height at Saline Condition }}{\text { Plant Height at Saline Condition }} \times 100
$$

\section{Statistical Analysis}

All obtained data were statistically analyzed according to the technique of analysis of variance (ANOVA) for the split - plot design [9]. By using means of "MSTAT-C" computer software package. Least Significant Difference (LSD) method was used to test the differences between treatment means at $5 \%$ level of probability [21].

\section{Results and Discussion Performance of Cultivars}

Results in Table 2 clearly showed that the ten tested cultivars of rice significantly varied for averages of root length $(\mathrm{cm})$, shoot length $(\mathrm{cm})$, root fresh weight $(\mathrm{mg})$, shoot fresh weight $(\mathrm{mg})$, root dry weight (mg), final germination percentage (FGP), germination rate $(G R)$, germination index $(G I)$, vigor index $(\mathrm{VI})$, relative dry weight (RDW) and seedling height reduction (SHR). Sakha 102, Sakha106, Sakha104, Giza 178 and Egyptian Yasmin cultivars significantly exceeded the other studied rice cultivars in final ger- 
mination percentage, without significant differences between them. It could be observed that both Sakha 102 and Sakha 106 cultivars more tolerant than other studied cultivars. In addition, Giza 178 and Egyptian Yasmin cvs moderate to salinity. The results clearly designated that Sakha 102, Sakha 104 and Giza 181 cultivars significantly surpassed the other studied cultivars in germination rate, without significant differences between them. Sakha102, Sakha 104, Giza 178 and Egyptian Yasmin cvs significantly surpassed other studied rice cultivars in germination index, without significant changes between them. Sakha 102, Sakha 104, Giza 178 and Egyptian Yasmin cvs was more tolerant to salinity up to $14 \% \mathrm{NaCl}$, while Sakha 105 was more sensitive to salinity.Sakha 106, Sakha 102 and Egyptian hybrid 1 CVs significantly surpassed the other studied cultivars in vigor index without significant differences between them. The differences between rice $\mathrm{CV}$ s in germination characters might be due to the genetical factors and heredity variation among the ten rice cvs under study which caused differed in germination characters. These results in good arrangement with those summarized that selected genotypes differently responded to salinity $[7,12,18]$.

Table 2- Averages of final germination percentage (\%), germination rate, germination index, vigor index, root length, shoot length, root fresh weight, shoot fresh weight, root dry weight, shoot dry weight, relative dry weight and seedling height reduction as affected by rice studied cultivars.

\begin{tabular}{|c|c|c|c|c|c|c|c|c|c|c|c|c|}
\hline $\begin{array}{l}\text { Cultivars } \\
\text { Performance }\end{array}$ & $\begin{array}{l}\text { FGP } \\
(\%)\end{array}$ & $\begin{array}{l}\text { GR } \\
\text { (days) }\end{array}$ & c & VI & $\begin{array}{l}\mathrm{RL} \\
(\mathrm{cm})\end{array}$ & $\begin{array}{l}\mathrm{SL} \\
(\mathrm{cm})\end{array}$ & $\begin{array}{l}\text { RFW } \\
\text { (mg) }\end{array}$ & $\begin{array}{l}\text { SFW } \\
\text { (mg) }\end{array}$ & $\begin{array}{l}\text { RDW } \\
\text { (mg) }\end{array}$ & $\begin{array}{l}\text { SDW } \\
\text { (mg) }\end{array}$ & $\begin{array}{l}\text { RDW } \\
(\%)\end{array}$ & $\begin{array}{l}\text { SHR } \\
(\%)\end{array}$ \\
\hline Sakha 102 & 98.92 & 3.54 & 99.25 & 11.81 & 6.69 & 5.17 & 0.039 & 0.112 & 0.01 & 0.016 & 61.88 & 38.2 \\
\hline Sakha 104 & 97.85 & 3.5 & 97.89 & 10.45 & 6.58 & 4.01 & 0.05 & 0.09 & 0.009 & 0.014 & 60.2 & 33.9 \\
\hline Sakha 105 & 80.71 & 2.78 & 82.71 & 8.82 & 5.91 & 4.03 & 0.02 & 0.084 & 0.007 & 0.014 & 64.47 & 36.4 \\
\hline Sakha 106 & 98.92 & 3.5 & 96.75 & 11.83 & 8.31 & 4.94 & 0.052 & 0.102 & 0.006 & 0.016 & 66.42 & 29 \\
\hline Giza 178 & 96.78 & 3.38 & 97.92 & 10.39 & 6.13 & 4.38 & 0.036 & 0.1 & 0.011 & 0.015 & 70.23 & 18.9 \\
\hline Giza 181 & 93.39 & 3.15 & 96 & 8.49 & 4.43 & 4.48 & 0.027 & 0.054 & 0.01 & 0.015 & 61.71 & 31.9 \\
\hline Giza 182 & 87.85 & 3.02 & 91.07 & 8.92 & 5.49 & 4.33 & 0.096 & 0.078 & 0.01 & 0.013 & 62.57 & 31.2 \\
\hline Egyptian Yasminn & 97.85 & 3.44 & 98.21 & 7.43 & 4.21 & 4.03 & 0.055 & 0.07 & 0.008 & 0.014 & 62.54 & 33.3 \\
\hline Egyptian Hybrid 1 & 89.28 & 3.08 & 93.14 & 11.64 & 7.17 & 5.42 & 0.065 & 0.091 & 0.011 & 0.017 & 70.89 & 24.5 \\
\hline Egyptian Hybrid 2 & 77.32 & 2.81 & 87 & 7.74 & 4.36 & 5.27 & 0.018 & 0.077 & 0.01 & 0.017 & 63.43 & 28.8 \\
\hline F. test & ** & ** & ** & $* *$ & ** & ** & ** & ** & ** & ** & ** & ** \\
\hline LSD $5 \%$ & 2.64 & 0.04 & 2.42 & 0.56 & 0.38 & 0.24 & 0.02 & 0.01 & 0.001 & 0.00 & 3.38 & 3.2 \\
\hline LSD $1 \%$ & 3.47 & 0.05 & 3.18 & 0.74 & 0.5 & 0.32 & 0.03 & 0.02 & 0.0018 & 7 & 3.64 & 4.2 \\
\hline
\end{tabular}

${ }^{*},{ }^{* *}$ and NS indicate $P<0.05, P<0.01$ and not significant, respectively

Sakha106 CV significantly outdone the other studied cultivars in root length in view of the fact that produced the tallest root length. Root length of Sakha 106 exceeded by $97.3 \%$ compared with Egyptian Yasmin CV and by $90.6 \%$ compared with Egyptian hybrid 2 and by $87.5 \%$ compared with Giza 181 CV. Egyptian Hybrid 1, Sakha 102 and Egyptian hybrid 2 CV significantly exceeded the other studied cvs without significant differences between them. Egyptian hybrid 1 CV exceeded Sakha 104 CV by 26.0\%, Sakha 105 CV by $25.6 \%$, Egyptian Yasmin CV by 25.6 , Giza 181 CV by $17.3 \%$, Giza 182 CV by $20.1 \%$, Giza 178 CV by $19.1 \%$ and Sakha 106 CV by $8.8 \%$ in shoot length. Giza 182 significantly surpassed other studied cultivars in root fresh weight followed by Egyptian Hybrid 1 and Egyptian Yasmin, respectively. Giza 182 CV surpassed Egyptian hybrid 2 CV by $81.25 \%$, Sakha 105 CV by $79.16 \%$, Giza 181 CV by $71.8 \%$, Giza 178 CV by $62.5 \%$, Sakha 102 CV by $59.37 \%$, Sakha 104 CV by $47.91 \%$, Sakha 106 CV by
45.83\%, Egyptian Yasmin CV by $42.7 \%$ and Egyptian hybrid 1 CV by $32.29 \%$ in root fresh weight. Giza 178 cultivar significantly exceeded the other studied CVs in shoot fresh weight $(\mathrm{mg})$ in view of the fact that produced the highest shoot fresh weight, followed with statistical significance by Sakha 102 and Sakha 106 CVs in the second and third ranks, respectively. It could be discerned that Giza 178 cv surpassed Giza 181 cv by $52.2 \%$, Giza 182 cv by $30.9 \%$, Egyptian hybrid 2 cv by $31.8 \%$, Egyptian Yasmin cv by $30.0 \%$, Sakha 105 cv by $25.6 \%$, Sakha 104 cv by $20.3 \%$, Egyptian hybrid $1 \mathrm{cv}$ by $16.9 \%$ and Sakha 106 cv by $9.7 \%$ in shoot fresh weight. Egyptian Hybrid 1, Egyptian hybrid 2, Sakha 102, Giza 178, Giza 181 and Giza 182 CVs significantly outdone other studied CVs in root dry weight, without significant differences between them. While, Sakha $106 \mathrm{CV}$ recorded the minimum weight of root dry weight, However, Sakha 102, Giza 181 and Giza 182 CVs recorded intermediate weights of root dry weight compared to the other studied CVs. Egyptian Hybrid 1, Egyptian Hybrid 2, Sakha 102 and Sakha 106 CVs significantly surpassed the other studied rice CVS in shoot dry weight without significant differences between them. Egyptian hybrid 1 and Giza 178 CVs significantly surpassed other studied cultivars in relative dry weight without significant differences between them. Sakha 102 and Sakha 105 CVs significantly exceeded other studied cvs in seedling height reduction percentage without significant differences between them. Followed by Sakha 104, Egyptian yasmin, Giza 181 and Giza 182 CVs, without significant differences between them. The differences between rice CVs in seedling parameters might be due to salt level side effects and to genetically factors and heredity variation among the ten studied CVs which differences in seedling parameters. Many similar deductions were reported with conclusion that salinity affect growth process and physiological consequences at advanced growth stages of genotypes $[4,11$, $12,18]$.

\section{Salinity Stress Effects}

The results in Table 3 indicated that salinity stress treatments had significant effects on means of root length $(\mathrm{cm})$, shoot length $(\mathrm{cm})$, root fresh weight $(\mathrm{mg})$, shoot fresh weight $(\mathrm{mg})$, root dry weight $(\mathrm{mg})$, final germination percentage (FGP), germination rate (GR), germination index $(\mathrm{GI})$, vigor index $(\mathrm{VI})$ and relative dry weight (RDW). Highest means of these fonts were recorded with control treatment. Highest salinity focus up to $14 \% \mathrm{NaCl}$ recorded the lowest averages of these characters. Increasing salinity concentrations from 0 to $14 \% \mathrm{NaCl}$ gradually decreased averages of root length $(\mathrm{cm})$, shoot length $(\mathrm{cm})$, root fresh weight $(\mathrm{mg})$, shoot fresh weight $(\mathrm{mg})$ and root dry weight $(\mathrm{mg})$. Highest final germination percentage $(96.87 \%)$ was recorded with the control treatment compared with other salinity concentrations, followed by 95.62 and $95.37 \%$ with $4 \%$ and $6 \% \mathrm{Nacl}$ without significant differences between them. Highest salinity concentration i.e. $14 \% \mathrm{NaCl}$ recorded the lowest final germination percentage which was $82.87 \%$. Germination percentage not affected from increasing salinity levels from $0 \%$ to $10 \% \mathrm{NaCl}$, however, increasing it to 12 and $14 \%$ $\mathrm{NaCl}$ significantly decreased final germination percentage. Highest number of germination rate was recorded with control treatment compared with other salinity concentrations. Highest salinity concentration i.e. $14 \% \mathrm{NaCl}$ recorded the lowest germination rate. Highest germination index was obtained from the control treat- 
ment and salinity at concentration of $4 \% \mathrm{NaCl}$ compared with other salinity stress concentrations without significant differences between them, which were 98.7 and $97.15 \%$ respectively. Highest of salinity concentrations at $14 \% \mathrm{NaCl}$ recorded the lowest germination index. Highest vigor index values was recorded with the control treatment compared with other salinity stress concentrations $(13.88 \%)$ followed by salinity concentration of 4 and $6 \%$ $\mathrm{NaCl}$ as an intermediate value of salinity concentrations. Highest salinity levels $14 \% \mathrm{NaCl}$ chronicled the lowest vigor index value. High levels of salinity affected on germination characters might be due to toxic effects of salinity stress. Salinity decreased germination typescripts of seeds which are directly related to the amount of absorbed water by the seed. $[5,8,12,13]$. Seed germination was quantitative trait controlled by several gens and strongly affect by salt stress [22].

Table 3- Averages of final germination percentage (\%), germination rate, germination index, vigor index, root length, shoot length, root fresh weight, shoot fresh weight, root dry weight, shoot dry weight, relative dry weight and seedling height reduction as affected by salinity concentrations ( $\mathrm{NaCl})$.

\begin{tabular}{lllllllllllll}
$\begin{array}{l}\text { Salinity } \\
\text { Stress }\end{array}$ & $\begin{array}{l}\text { FGP } \\
(\%)\end{array}$ & GR & GI & VI & $\begin{array}{l}\text { RL } \\
(\mathrm{cm})\end{array}$ & $\begin{array}{l}\text { SL } \\
(\mathrm{cm})\end{array}$ & $\begin{array}{l}\text { RFW } \\
(\mathrm{mg})\end{array}$ & $\begin{array}{l}\text { SFW } \\
(\mathrm{mg})\end{array}$ & $\begin{array}{l}\text { RDW } \\
(\mathrm{mg})\end{array}$ & $\begin{array}{l}\text { SDW } \\
(\mathrm{mg})\end{array}$ & $\begin{array}{l}\text { RDW } \\
(\%)\end{array}$ & $\begin{array}{l}\text { SHR } \\
(\%)\end{array}$ \\
\hline $\mathrm{O}(\mathrm{control})$ & 96.87 & 3.45 & 98.7 & 13.88 & 8.89 & 6.63 & 0.099 & 0.138 & 0.016 & 0.022 & 100 & 0 \\
$4 \% \mathrm{NaCl}$ & 95.62 & 3.37 & 97.15 & 13.14 & 8.19 & 6.07 & 0.063 & 0.123 & 0.013 & 0.021 & 90.36 & 9.7 \\
$6 \% \mathrm{NaCl}$ & 95.37 & 3.32 & 96.57 & 11.84 & 6.96 & 5.4 & 0.045 & 0.1 & 0.011 & 0.018 & 77.78 & 19 \\
$8 \% \mathrm{NaCl}$ & 93.12 & 3.26 & 95.42 & 10.66 & 6.41 & 4.8 & 0.042 & 0.085 & 0.009 & 0.015 & 63.65 & 27.7 \\
$10 \% \mathrm{NaCl}$ & 90.75 & 3.18 & 93.65 & 8.5 & 5.1 & 3.9 & 0.038 & 0.07 & 0.007 & 0.013 & 51.76 & 41.5 \\
$12 \% \mathrm{NaCl}$ & 88.62 & 3.07 & 91.2 & 6.06 & 3.42 & 3.19 & 0.017 & 0.057 & 0.005 & 0.01 & 40.11 & 51.4 \\
$14 \% \mathrm{NaCl}$ & 82.87 & 2.89 & 85.27 & 4.19 & 2.51 & 2.27 & 0.016 & 0.043 & 0.003 & 0.007 & 27.4 & 64.9 \\
$\mathrm{~F}$ test & $* *$ & $* *$ & $* *$ & $* *$ & $* *$ & $* *$ & $* *$ & $* *$ & $* *$ & $* *$ & $* *$ & $* *$ \\
LSD at 5\% & 2.21 & 0.03 & 2.02 & 0.46 & 0.31 & 0.2 & 0.023 & 0.013 & 0.0011 & 0.0008 & 2.83 & 2.7 \\
LSD at $1 \%$ & 2.9 & 0.04 & 2.66 & 0.61 & 0.41 & 0.27 & 0.029 & 0.017 & 0.0014 & 0.001 & 3.71 & 3.6 \\
\hline
\end{tabular}

${ }^{*},{ }^{* *}$ and NS indicate $P<0.05, P<0.01$ and not significant, respectively

Tallest root length was recorded with the control treatment compared with other salinity stress levels. Highest salinity level i.e. $14 \% \mathrm{NaCl}$ reduced root length and recorded the lowest root length. The second salinity level i.e. $6 \% \mathrm{NaCl}$ came in the second rank. It could be concluded that reducing salinity levels from $14 \%$, $12 \%, 10 \%, 8 \%, 6 \%$ to $4 \% \mathrm{NaCl}$ reduced root length by $71.7 \%$, $61.5 \%, 42.6 \%, 28.0 \% 21.7 \%$ and $7.5 \%$ respectively compared with control treatment. Reducing salinity levels from $14 \%, 12 \%$, $10 \%, 8 \%, 6 \%$ to $4 \% \mathrm{NaCl}$ reduced shoot length by $65.7 \%$, $51.88 \%, 41.17 \%, 27.6,18.55 \%$ and $8.44 \%$, respectively compared without salinity i.e. control treatment. Highest weight of root fresh was obtained with the control treatment compared with other salinity levels, followed by $4 \% \mathrm{NaCl}$ and $6 \% \mathrm{NaCl}$ as intermediate values. Highest salinity level i.e. $14 \% \mathrm{NaCl}$ recorded the lowest root fresh weight. Reducing salinity levels from 14\%,12\%, 10\%, $8 \%, 6 \%$ to $4 \% \mathrm{NaCl}$ reduced shoot fresh weight by $68.84 \%$, $58.19 \%, 49.2 \%, 38.4 \%, 27.5$, and $10.86 \%$ compared with the control treatment. Highest root dry weight was obtained from the control treatment compared with other salinity levels. Increasing salinity level to 4 and $6 \% \mathrm{NaCl}$ came in the second and third rank after control. Highest salinity level $14 \% \mathrm{NaCl}$ was recorded the lowest root dry weight. Highest shoot dry weight was obtained from the control treatment compared with other salinity levels, followed by 4 and $6 \% \mathrm{NaCl}$ as intermediate values. Highest salini- ty level i.e. $14 \% \mathrm{NaCl}$ recorded the lowest shoot dry weight. Highest relative dry weight was obtained from the control treatment compared with other salinity levels which was $100.0 \%$, followed by salinity concentrations of 4 and $6 \% \mathrm{NaCl}$ as an intermediate value of salinity levels. Highest salinity level of $14 \% \mathrm{NaCl}$ recorded the lowest relative dry weight. Relative dry weight gradually decreased with increasing of salinity levels. Highest seedling height reduction was obtained from the salinity level of $14 \% \mathrm{NaCl}$ treatment compared with other salinity concentrations, followed by salinity levels of 12 and $10 \% \mathrm{NaCl}$ as an intermediate values of salinity levels. The control treatment recorded the lowest percentages of seedling height reduction value, followed by salinity level of 4 and $6 \% \mathrm{NaCl}$. The gradual decrease in seedling parameters with the increase in salinity as observed might be due to more inhibitory effect of $\mathrm{NaCl}$ salt to root growth compared to that of shoot growth and to sodium level in the shoots during early growth. In addition to the cellular toxicity of $\mathrm{NaCl}$ in rice seedlings and reduction of chlorophyll content under saline condition. $[5,8,10]$. Salinity decreased final germination percentage, speed of germination, germination energy percentage and led to reduction in shoot and root length and dry weight in all studied varieties and the magnitude of reduction increased with increasing salinity stress [11].

\section{Interaction Effects}

The interaction between rice cultivars and salinity levels significantly affected final germination percentage as shown in Fig. 1. Highest final germination percentage was produced from Sakha 102 and Sakha 106 cultivars with snowballing salinity levels up to $10 \% \mathrm{NaCl}$. Whereas, the lowest final germination percentages were resulted from sowing Sakha 105 and Egyptian Hybrid 2 cultivars at higher salinity levels of $14 \% \mathrm{NaCl}$ without significant differences between them. Highest averages of germination rate were resulted from sowing Sakha 106, Sakha 104 and Egyptian Yasmin cvs and increasing salinity concentrations up to $10 \% \mathrm{NaCl}$ without significant differences between them as shown in Fig. 2. The lowest average of germination rate was resulted from sowing Sakha 105 and Egyptian hybrid 2 cultivars at higher salinity level of $14 \%$ $\mathrm{NaCl}$ without significant differences between them. Uppermost germination index was recorded with Sakha 102 and Sakha 106 cultivars with increasing salinity level up to $10 \% \mathrm{NaCl}$ without significant differences between them as shown in Fig. 3. On contrary, the lowest value of germination index was resulted from sowing Sakha 105 with higher salinity level of $14 \% \mathrm{NaCl}$. In addition, uppermost vigor index percentages were resulted from sowing Sakha 102 CV and the control treatment as shown in Fig. 4. On conflicting, the lowest percentage of vigor index was resulted from Sakha 104 or Giza 181 cultivar with highest salinity levels of $14 \% \mathrm{NaCl}$. Tallest root length was chronicled with Sakha 106 cultivar and the control treatment as shown in Fig. 5. Whilst, the shortest in root length were caused from sowing Sakha 104 or Giza 181 with high salinity concentration i.e.14\% NaCl. Moreover, tallest shoot length was obtained from all studied cultivars at control treatment. Sakha 102 and Egyptian hybrid 1 at control treatment twisted tallest shoot length as shown in Fig. 6 .The shortest shoot length was obtained from Giza 181, Sakha 105 and Sakha 104 cvs without significant differences between them. Highest shoot dry weight was resulted from sowing Egyptian Hybrid 1, 
Sakha 102, Sakha 104, Sakha 106 and Egyptian Yasmin cvs and control treatment without significant differences between them as shown in Fig. 7. The lowest shoot dry weight was resulted from sowing Giza 181, Giza 182 and Sakha 104 cvs and salinity concentration of $14 \% \mathrm{NaCl}$ without significant differences between them. Highest relative dry weight percentages were resulted from sowing all studied cvs with control treatment as shown in Fig. 8. Snowballing salinity levels from $4 \% \mathrm{NaCl}$ to $14 \% \mathrm{NaCl}$ significantly reduced relative dry weight in all studied cvs. The lowest percentage of relative dry weight was resulted from sowing Giza 181, Giza 182 and Sakha 104 cvs with highest salinity levels of 14\% $\mathrm{NaCl}$. Highest percentages of seedling height reduction was occasioned from sowing Giza181 cultivar with salinity level of 14\% $\mathrm{NaCl}$ treatment, followed by Sakha 102, Sakha 104 and Sakha 105 with salinity level of $14 \% \mathrm{NaCl}$ without significant differences between them as shown in Fig. 9. The lowest percentages of seedling height reduction were resulted from sowing all studied cvs with control treatment. Differences between cultivars tolerance to salinity may be due to higher proline, protein and starch content under salt stress [3]. Salt stress decreased vigor of all studied rice cultivars [17] .

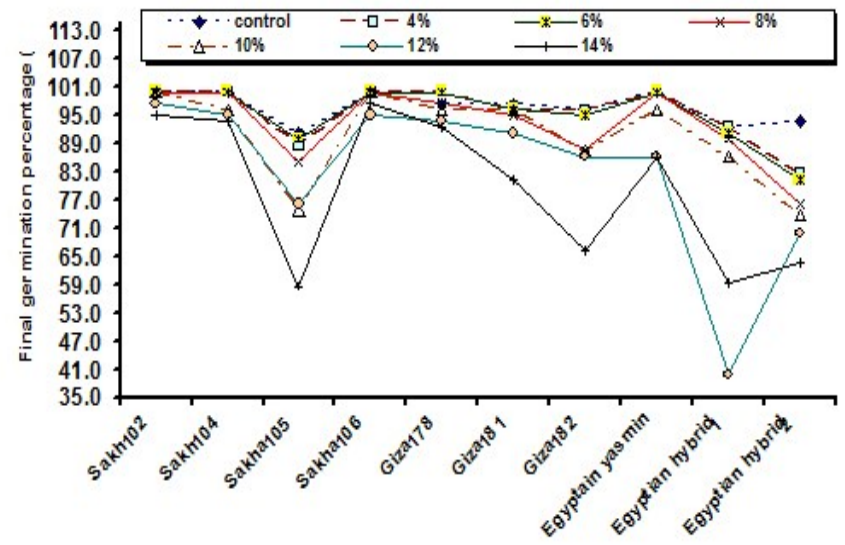

Fig. 1- Averages final germination percentage (\%) as affected by the interaction between cultivars and salinity stress ( $\mathrm{NaCl} \%)$.

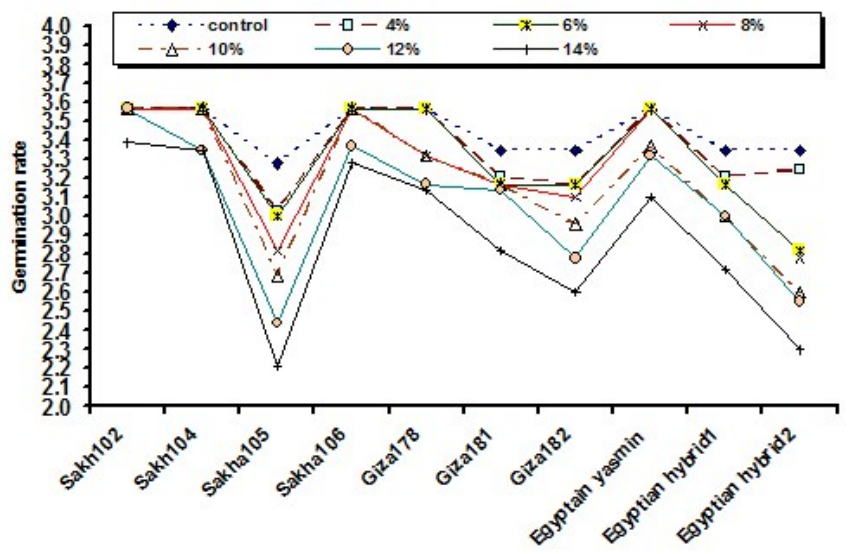

Fig. 2- Averages germination rate as affected by the interaction between cultivars and salinity stress $(\mathrm{NaCl} \%)$.

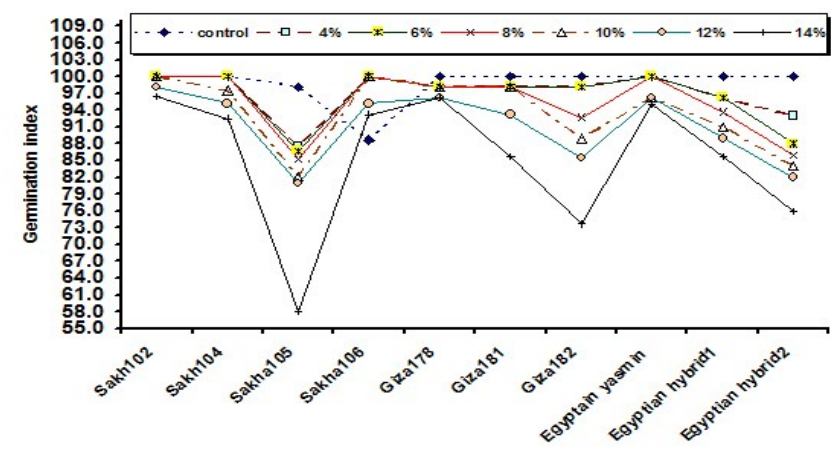

Fig. 3- Averages germination index $\%$ as affected by the interaction between cultivars and salinity stress $(\mathrm{NaCl} \%)$.

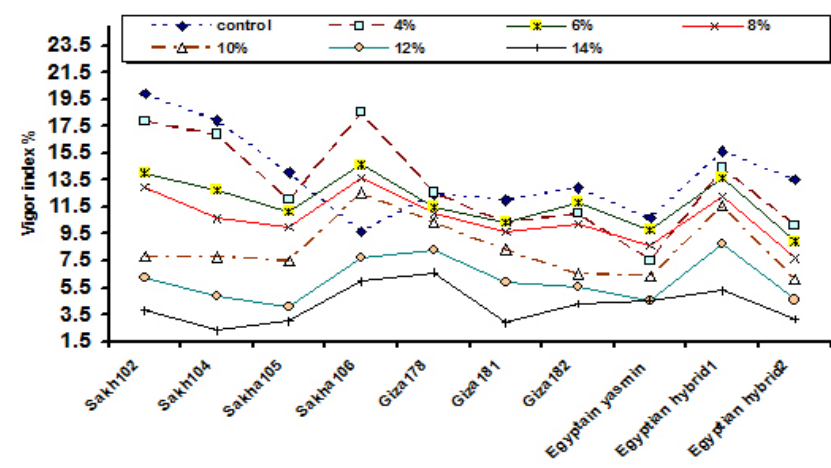

Fig. 4- Averages vigor index \% as affected by the interaction between cultivars and salinity stress $(\mathrm{NaCl} \%)$.

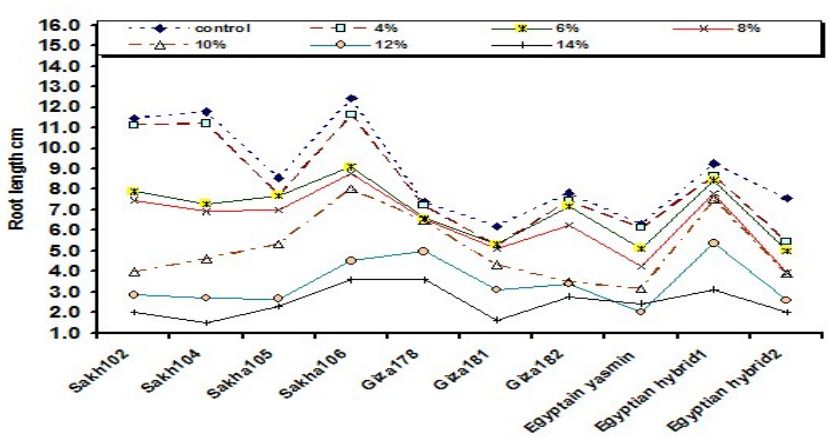

Fig.5- Averages root length $\mathrm{cm}$ as affected by the interaction between cultivars and salinity stress $(\mathrm{NaCl} \%)$.

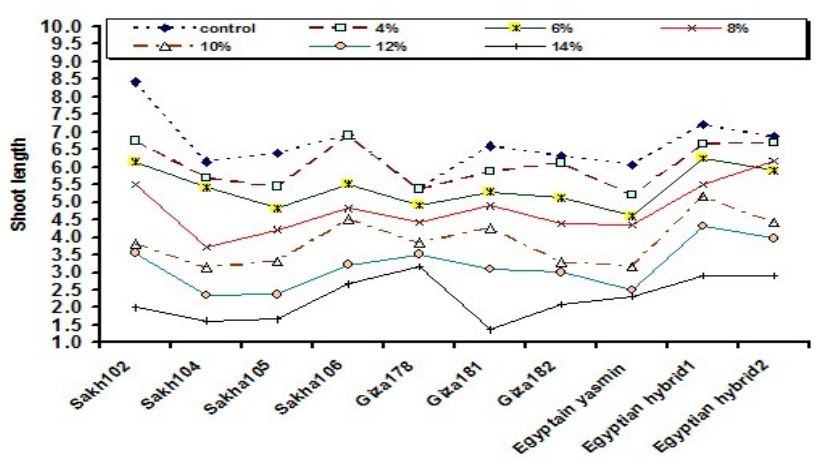

Fig. 6- Averages shoot length $\mathrm{cm}$ as affected by the interaction between cultivars and salinity stress $(\mathrm{NaCl} \%)$. 


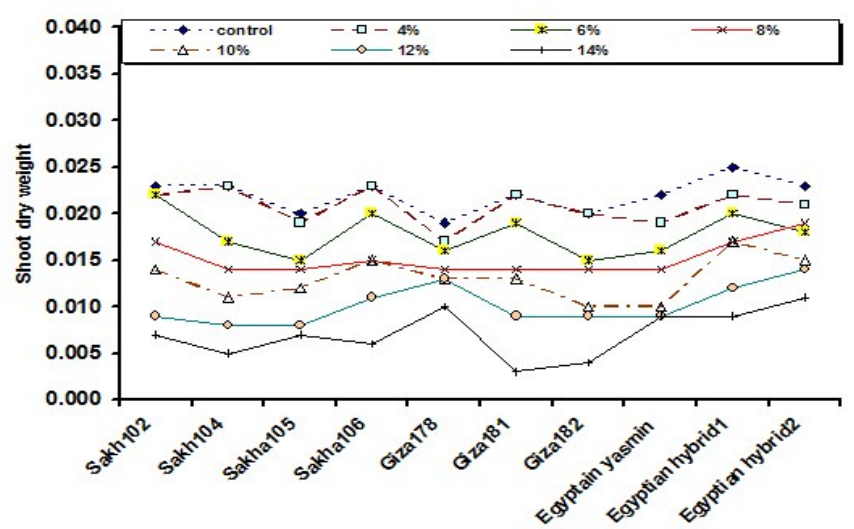

Fig7- Averages shoot dry weight mg as affected by the interaction between cultivars and salinity stress $(\mathrm{NaCl} \%)$.

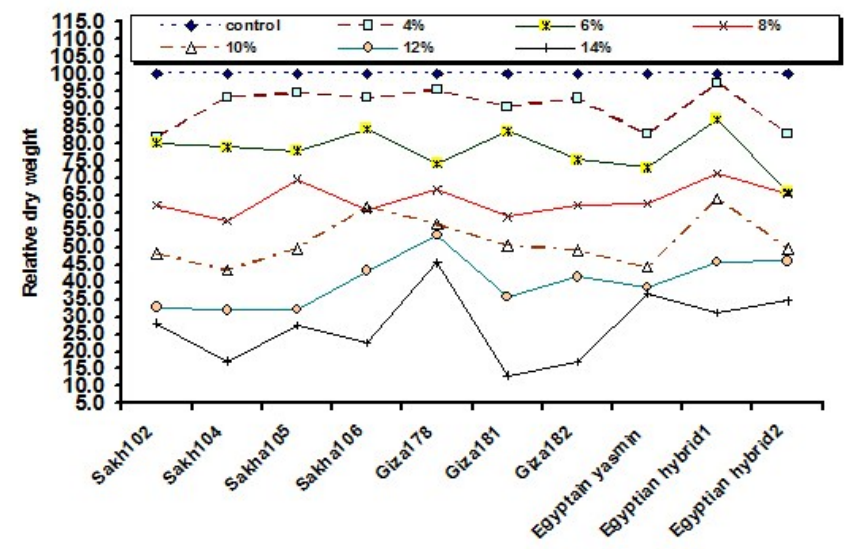

Fig.8- Averages relative dry weight $\%$ as affected by the interaction between cultivars and salinity stress ( $\mathrm{NaCl} \%)$.

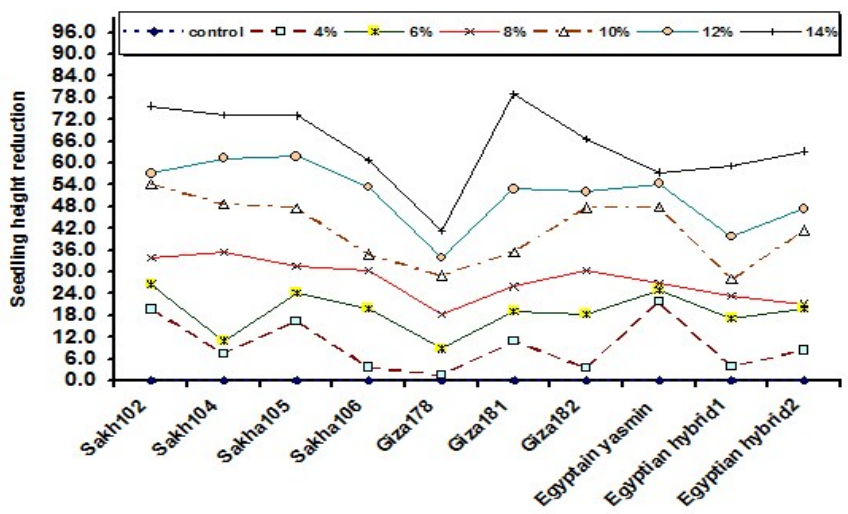

Fig. 9- Percentages seedling height reduction \% as affected by the interaction between cultivars and salinity stress $(\mathrm{NaCl} \%)$.

\section{Conclusion}

It could be concluded that for maximizing rice germination percentage and seedling parameters under salinity stress are producing by using rice Sakha 102, Sakha 106, Sakha 104 and Egyptian Yasmin cultivars under salinity levels level up to $14 \%$ $\mathrm{NaCl}$. These cultivars were more tolerant to salinity and recommended to use them in breeding program for enhancing rice production in Egypt.

\section{Abbreviations}

- FGP: Final Germination Percentage

- GR: Germination Rate

- GI: Germination Index

- VI: Vigor Index

- RL: Root Length

- SL: Shoot Length

- RFW: Root Fresh Weight

- SFW: Shoot Fresh Weight

- RDW: Root Dry Weight

- SDW: Shoot Dry Weight

- SHR: Seedling Height Reduction

\section{References}

[1] Bhuiyan N.I., Paul D.N.R. and Jabber M.A. (2002) National Workshop on Rice Research and Extension.

[2] Cha-um S., Trakulyingcharoen T., Smitamana P. and Kirdmanee C. (2009) Aust. J. Crop Sci., 3(4), 221-230.

[3] Danai-Tambhale S., Kumar V. and Shriram V. (2011) J. Stress Physiol. Biochem., 7, 387-397.

[4] Djanaguiraman M., Senthil A. and Ramadass R. (2003a) Madras Agric. J., 90(7-9), 506-510.

[5] Djanaguiraman M., Ramadass R. and Devi D.D. (2003b) Madras Agric. J., 90 (1-3), 50-53.

[6] Ellis R.H. and Roberts E.H. (1980) Towards a Rational Basis for Testing Seed Quality, 605-635.

[7] Ellis R.H. and Roberts E.H. (1981) Seed Sci. Technol., 9, 373409.

[8] Golshani M., Pirdashti H., Saeb K., Babakhani B. and Heidarzade A. (2010) World Applied Sci. J., 9 (2), 221-225.

[9] Gomez K.A. and Gomez A.A. (1984) Statistical Procedures for Agricultural Research, 2nd edition, 680.

[10]Habib N., Muhammad A. and Ahmad M.S.A. (2010) Pak. J. Bot., 42(6), 4071-4078.

[11]Hakim M.A., Juraimi A.S., Begum M., Hanafi M.M., Ismail M.R. and Selamat A. (2010) Afric. J. Biotech., 9(13), 19111918.

[12]Islam M.M. and Karim M.A. (2010) The Agricult., 8(2), 57-65.

[13]Jamil M. and Rha E.S. (2007) Pak. J. Biol. Sci., 10, 43034306.

[14]Joseph B. and Jini D. (2010) Int. J. Bot., 10, 456-464.

[15]Joseph B., Jini D. and Sujatha S. (2010) Asian J. of Agric. Sci., 2(3), 99-105.

[16]Karim M.A., Utsunomiya N. and Shigenaga S. (1992) J. Crop Sci. 61, 279- 284.

[17]Kazemi K. and Eskandari H. (2011) African Journal of Biotechnology, 10(77), 17789-17792.

[18]Rahman M.S., Miyake H. and Takeoka Y. (2001) Pak. J. Biol. Sci., 4(3), 351-355.

[19]Ruan S., Xue Q. and Thlkowska K. (2002) Seed Sci. Technol. 30, 451-458.

[20]Saeidzadeh F., Gurbanov E. and Dunyamaliyev S.A. (2011) Son Yenilenme Pazar Ertesi., 4, 23-32.

[21]Snedecor G.W. and Cochran W.G. (1980) Statistical Methods" 7th Ed., 507.

[22]Zhoufei W., Jianfei W., Yunyu B. and Hongsheng Z. (2011) Euphytica., 178(3), 297-307. 